\title{
Seasonal influenza vaccine and Guillain-Barré syndrome
}

\author{
A self-controlled case series study
}

Clémence Grave, MD, Pauline Boucheron, MD, MSc, Jérémie Rudant, MD, PhD, Yann Mikaeloff, MD, PhD, Pascale Tubert-Bitter, PhD, Sylvie Escolano, PhD, Mounia N. Hocine, PhD, Joël Coste, MD, PhD, and Alain Weill, MD

Neurolog ${ }^{\circledR}$ 2020;94:2168-2179. doi:10.1212/WNL.0000000000009180

\section{Abstract}

\section{Objective}

To evaluate the risk of Guillain-Barré syndrome (GBS) following seasonal influenza vaccination based on French nationwide data.

\section{Methods}

All cases of GBS occurring in metropolitan France between September 1 and March 31 from 2010 to 2014 were identified from the French national health data system. Data were analyzed according to the self-controlled case series method. The risk period started 1 day after the patient received vaccine (D1) until 42 days after vaccination (D42). The incidence of GBS during this risk period was compared to that of the control period (D43-March 31). The incidence rate ratio (IRR) was estimated after adjusting for seasonality and presence or not of acute infections.

\section{Results}

Between September and March, of the 2010/2011 to 2013/2014 influenza vaccination seasons, 3,523 cases of GBS occurred in metropolitan France and were included in the study. Among them, 15\% (527 patients) had received influenza vaccination. A total of 140 patients developed GBS during the 42 days following influenza vaccination. The crude risk of developing GBS was not significantly increased during the 42 days following influenza vaccination (IRR, 1.02; 95\% confidence interval $[\mathrm{CI}], 0.83-1.25 ; p=0.85)$. This result remained nonsignificant after adjustment for calendar months and the incidence of acute gastrointestinal and respiratory tract infections (IRR, 1.10; 95\% CI, 0.89-1.37; $p=0.38$ ). In contrast, the risk of GBS was fourfold higher after acute respiratory tract infection (IRR, 3.89; 95\% CI, 3.52-4.30; $p<0.0001$ ) or gastrointestinal infection (IRR, 3.64; 95\% CI, 3.01-4.40; $p<0.0001$ ).

\section{Conclusions}

No association between seasonal influenza vaccination and GBS was shown during the 42 days following vaccination.

\author{
Correspondence \\ Dr. Grave \\ grave.clemence@gmail.com
}




\section{Glossary}

$\mathbf{A D}=$ associated diagnosis; $\mathbf{A T C}=$ anatomical therapeutic chemical; $\mathbf{C I}=$ confidence interval; $\mathbf{C I P}=$ code identifiant de présentation; GBS = Guillain-Barré syndrome; ICD-10 = International Classification of Diseases-10; IRR = incidence rate ratio; PD = principal diagnosis; PMSI = Programme de Médicalisation des Systèmes d'Information; RD = related diagnosis; SCCS $=$ self-controlled case series; SNIIRAM = Système National d'Information Interrégimes de l'Assurance Maladie.

Guillain-Barré syndrome (GBS) is an acute polyneuropathy with a worldwide estimated incidence ranging from 0.3 to 2.5 person-years. ${ }^{1,2}$ GBS is usually preceded by infection that induces an aberrant autoimmune response. ${ }^{3}$ Stimulation of the immune system by vaccination could also increase the risk of autoimmunity and of GBS. Some studies have demonstrated an association between GBS and certain vaccines, such as an old version of rabies vaccine $e^{4}$ or human papillomavirus vaccine. ${ }^{5-7}$ Several studies also reported a 3 - to 10 -fold higher rate of GBS during the 6 weeks following the 1976 US influenza vaccination. ${ }^{4,5,8-10}$ In 2009 , a large-scale vaccination campaign was conducted during the influenza A pandemic. A possible increased risk of GBS was discussed following this vaccination. ${ }^{11-13}$ A meta-analysis conducted by Martín Arias et al. ${ }^{14}$ revealed a slight association between GBS and the 2009 influenza vaccination. Seasonal influenza vaccine is more difficult to monitor, as the constituent strains of the vaccine vary each year. Its association with GBS remains uncertain. ${ }^{14-17}$ Moreover, influenza virus infection itself also appears to be a risk factor for GBS, making it difficult to interpret the association between influenza vaccination and GBS. $^{18-21}$

Each year, the national health care insurance funds influenza vaccination campaigns in France. We determined the risk of GBS following seasonal influenza vaccination from 2010 to 2014 in a real-world study, using the French national health care insurance database, which contains claims and hospital health records of about 66 million citizens. ${ }^{22}$

\section{Methods}

\section{Data sources}

A self-controlled case series (SCCS) was performed using the French claims database.

French national health insurance covers the health care of more than $99 \%$ of the residents of France. Hospitalizations in public or private hospitals, paraclinical examinations, biological examinations, medical consultations, paramedical procedures, and the majority of drugs are funded or reimbursed by French national health insurance. All these health expenses are recorded in French claims databases, the French national health insurance system database (Système National d'Information Interrégimes de l'Assurance Maladie [SNIIRAM]) and the national hospital discharge database (Programme de Médicalisation des Systèmes d'Information [PMSI]), which are linked by means of a unique anonymous identifier allocated to each individual. ${ }^{22-25}$ These databases provide detailed information on real-life management of the population living in France (about 65,000,000 people).

The SNIIRAM contains comprehensive individualized and anonymous data on all outpatient services reimbursed by French national health insurance, including drugs, physician visits, and laboratory or imaging investigations. Drug dispensing is identified by means of a CIP code (Code Identifiant de Présentation) unique for each product and each packaging, ${ }^{22}$ from which detailed Anatomical Therapeutic Chemical (ATC) codes are determined.

The PMSI database reports all hospital stays in both public and private hospitals. It contains the principal diagnosis (PD), related diagnosis $(\mathrm{RD})$, and associated diagnosis $(\mathrm{AD})$ coded according to the ICD-10. The principal diagnosis corresponds to the disease justifying admission to the medical unit. Diagnoses are provided by a physician for each medical unit in which the patient has been hospitalized and are determined at the end of the stay using medical records. The PMSI database also contains information on expensive drugs administered in the hospital, such as immunoglobulins, and certain procedures performed during the hospital stay.

\section{Study population}

All incident cases of GBS hospitalized between January 1, 2010, and December 31, 2014, were identified from the PMSI database using the ICD-10 code G61.0 in any medical unit. In order to be included, patients had to have no identifiable prior GBS event in the database, that is, not have been hospitalized in relation to GBS (GBS code [G61.0] in any position [PD/ $\mathrm{RD} / \mathrm{AD}]$ ) between 2006 and 2009.

For each patient, the date of GBS diagnosis (index date) was defined as the admission date in the first hospital unit with GBS coded (G61.0) during the study period. However, if the included patient had a previous hospitalization (ending the day before hospitalization for GBS) with a symptom or a complication of GBS coded as PD, then the index date was defined as the admission date in this prior hospitalization. $^{2}$

We included in this analysis cases of GBS that occurred between September 1 and March 31 of 2010-2014, which correspond to the 2010-2011, 2011-2012, 2012-2013, and 2013-2014 influenza seasons. Patients living outside of the French metropolitan area (i.e., in overseas departments), having a confidential or incorrect department of residence, 
Figure 1 Definition of the different observation periods of the study

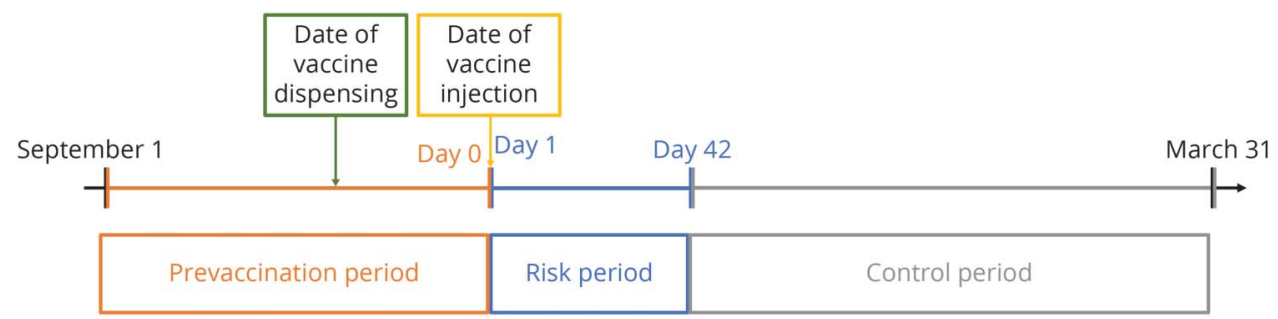

who died during the observation period, or for whom the date of vaccination could not be ascertained were excluded.

\section{Exposure assessment}

Each year, the national health care insurance funds influenza vaccination campaigns in France for citizens over 65 years old or with chronic diseases between September and January 31. This target population receives an invitation to be vaccinated against influenza. People get their reimbursed vaccine dispensed at the pharmacy. They are then vaccinated by a general practitioner, nurse, or midwife. This campaign leads to more than 5 million people being vaccinated each year. Since the 2010-2011 campaign, the influenza vaccine includes the H1N1, H3N2, and B strains. ${ }^{26-29}$

Influenza vaccines dispensed between 2010 and 2014 were identified from the SNIIRAM database by means of the ATC code (J07BB01, J07BB02, J07X) and CIP code. The date of influenza vaccine injection was estimated by assuming that it was performed at the time of first contact with a general practitioner, nurse, or midwife following dispensing of the vaccine. Therefore, we defined the date of influenza vaccine

Figure 2 Flow chart of the study

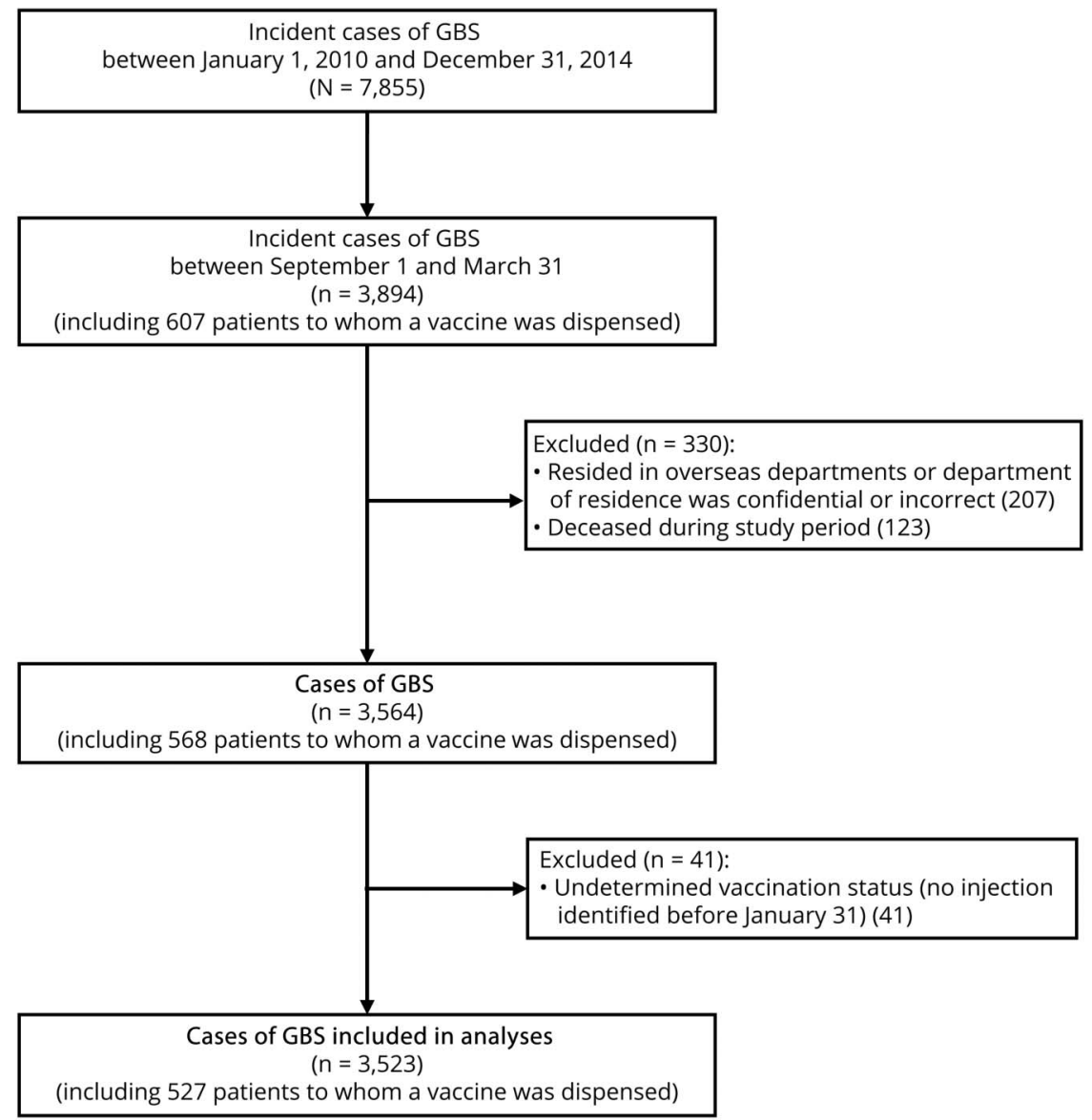

GBS = Guillain-Barré syndrome. 
injection as the date of first reimbursed act among the following events: general practitioner consultation, nurse act, or midwife act. Concerning patients who were reimbursed for influenza vaccine dispensing, but who did not subsequently consult a general practitioner, nurse, or midwife before the end of the French influenza campaign (January 31), the date of vaccination could not be determined and these patients were excluded from the analysis as they met the exclusion criteria described above.

\section{Confounding factors}

Clinically diagnosed acute gastrointestinal and respiratory tract infections were identified by the dispensing of drugs used specifically for the treatment of infections and covered by French national health insurance: respiratory tract antibiotics, antidiarrheals, intestinal adsorbents, antipropulsives, influenza antiviral agents, and cough and cold preparations. Hospital discharge diagnoses (PDs or RDs) were also used. ${ }^{30}$

\section{Statistical analysis}

We used the SCCS method to investigate the association between GBS and influenza vaccination. ${ }^{31-33}$ In SCCS, each patient's follow-up time is divided into several periods: a period exposed, defined as the risk period, and an unexposed period, defined as the control period (figure 1).

We defined the day of influenza vaccination as day 0 . For each patient, a risk period started 1 day after the patient received the vaccine (day 1 ) until 42 days after vaccination (day 42 ). This 42-day duration was defined on the basis of existing literature ${ }^{13,34,35}$ and in particular the initial risk observed in $1976 .^{8-10}$ The control period started from 43 days after vaccination and ended on March 31 (day 43 to March 31).31,36 The prevaccination period started from September 1 to the day of influenza vaccination (September 1 to day 0 ). This prevaccination period was not included in the control period because a history of GBS may be considered a contraindication to vaccination by some patients and some physicians. ${ }^{12}$ To check if the GBS rate differed during this prevaccination period, we also compared this period to the control period.

The incidence rate ratio (IRR) of GBS associated with influenza vaccination was estimated by fitting a conditional Poisson regression model. The incidence of GBS during the risk period was compared to the incidence of GBS during the control period. Adjustments for variables dependent on seasonality (calendar month) and infections (acute respiratory tract and gastrointestinal infections) were performed.

Then we evaluated the risk of GBS according to the influenza vaccination season. Cochran $Q$ test was used to assess heterogeneity. Analyses were performed according to the patient's age: less than or greater than 65 years. An analysis excluding younger ( $<5$ years) and older patients ( $\geq 90$ years) and an analysis according to the type of vaccine (split-virion vs subunit influenza vaccine) were also performed. Analyses were also confined to cases for which the interval between dispensing and injection was less than 4 days. Finally, we conducted analyses on patients treated with immunoglobulins or plasma exchange and the most serious cases, who were admitted to the intensive care unit or who required

Table 1 Demographic and medical characteristics of patients with Guillain-Barré syndrome (GBS) included in the study

\begin{tabular}{lll}
\hline & All & Vaccinated patients \\
\hline No. of GBS cases & 3,523 & 527 \\
\hline Age, $\mathbf{y}$ & & \\
\hline Mean (SD) & $51.1(21.8)$ & $73.0(9.2)$ \\
\hline Median (Q1-Q3) & $55(36-68)$ & $74(67-80)$ \\
\hline Min-max & $0-93$ & $17-93$ \\
\hline
\end{tabular}

Age distribution, $y, n(\%)$

\begin{tabular}{lll}
\hline $\mathbf{0 - 9}$ & $194(5.5)$ & $0(0.0)$ \\
\hline $\mathbf{1 0 - 1 9}$ & $176(5.0)$ & $1(0.2)$ \\
\hline $\mathbf{2 0 - 2 9}$ & $286(8.1)$ & $0(0.0)$ \\
\hline $\mathbf{3 0 - 3 9}$ & $374(10.6)$ & $1(0.2)$ \\
\hline $\mathbf{4 0 - 4 9}$ & $407(11.6)$ & $5(0.9)$ \\
\hline $\mathbf{5 0 - 5 9}$ & $637(18.1)$ & $36(6.8)$ \\
\hline $\mathbf{6 0 - 6 9}$ & $677(19.2)$ & $134(25.4)$ \\
\hline $\mathbf{7 0 - 7 9}$ & $526(14.9)$ & $215(40.8)$ \\
\hline $\mathbf{8 0 - 8 9}$ & $238(6.8)$ & $130(24.7)$ \\
\hline $\mathbf{9 0 - 9 9}$ & $8(0.2)$ & $5(0.9)$ \\
\hline Sex & $1,465(41.6)$ & $189(35.9)$ \\
\hline Men & $2,058(58.4)$ & $338(64.1)$ \\
\hline Women & & \\
\hline
\end{tabular}

Month of onset of GBS

\begin{tabular}{lll}
\hline September & $354(10.0)$ & $29(5.5)$ \\
\hline October & $419(11.9)$ & $47(8.9)$ \\
\hline November & $491(13.9)$ & $68(12.9)$ \\
\hline December & $493(14.0)$ & $74(14.0)$ \\
\hline January & $662(18.8)$ & $127(24.1)$ \\
\hline February & $555(15.8)$ & $93(17.6)$ \\
\hline March & $549(15.6)$ & $89(16.9)$ \\
\hline
\end{tabular}

Medical care

\begin{tabular}{lll}
\hline Immunoglobulin & $2,735(77.6)$ & $417(79.1)$ \\
\hline Plasma exchange & $122(3.5)$ & $16(3.0)$ \\
\hline Mechanical ventilation & $485(13.8)$ & $85(16.1)$ \\
\hline Intensive care unit & $1,055(29.9)$ & $175(33.2)$ \\
\hline Median length of stay, d & 12 & 15 \\
\hline
\end{tabular}


Table 2 Description of vaccinated patients according to the year of diagnosis of Guillain-Barre syndrome (GBS)

\begin{tabular}{|c|c|c|c|c|}
\hline Date of GBS & $\begin{array}{l}\text { September 1, 2010, } \\
\text { to March 31, } 2011\end{array}$ & $\begin{array}{l}\text { September 1, 2011, } \\
\text { to March 31, } 2012\end{array}$ & $\begin{array}{l}\text { September 1, 2012, } \\
\text { to March 31, } 2013\end{array}$ & $\begin{array}{l}\text { September 1, 2013, } \\
\text { to March 31, } 2014\end{array}$ \\
\hline Number of vaccinated GBS cases & 140 & 138 & 130 & 119 \\
\hline \multicolumn{5}{|l|}{ Type of vaccine, $\mathbf{n}(\%)$} \\
\hline Split-virion inactivated influenza vaccine & $92(65.7)$ & $89(64.5)$ & $93(71.5)$ & $74(62.2)$ \\
\hline Inactivated subunit influenza vaccine & $48(34.3)$ & $49(35.5)$ & $37(28.5)$ & $45(37.8)$ \\
\hline \multicolumn{5}{|l|}{$\begin{array}{l}\text { Type of procedure used to identify the date } \\
\text { of injection, } n(\%)\end{array}$} \\
\hline $\begin{array}{l}\text { Medical consultation (general } \\
\text { practitioner) only }\end{array}$ & $94(67.1)$ & $89(64.5)$ & $77(59.2)$ & $79(66.4)$ \\
\hline Nursing consultation only & $40(28.6)$ & $45(32.6)$ & $46(35.4)$ & $36(30.3)$ \\
\hline Midwife consultation & $0(0.0)$ & $0(0.0)$ & $0(0.0)$ & $0(0.0)$ \\
\hline $\begin{array}{l}\text { Combination of general practitioner } \\
\text { consultation and nursing procedure }\end{array}$ & $6(4.3)$ & $4(2.9)$ & $7(5.4)$ & $4(3.4)$ \\
\hline \multicolumn{5}{|l|}{ Month of dispensing, $\mathrm{n}(\%)$} \\
\hline September & $24(17.1)$ & $13(9.4)$ & $8(6.2)$ & $3(2.5)$ \\
\hline October & $84(60.0)$ & $80(58.0)$ & $87(66.9)$ & $66(55.5)$ \\
\hline November & $23(16.4)$ & $37(26.8)$ & $24(18.5)$ & $44(37.0)$ \\
\hline December & $9(6.4)$ & $8(5.8)$ & $10(7.7)$ & $5(4.2)$ \\
\hline January & $0(0.0)$ & $0(0.0)$ & $1(0.8)$ & $1(0.8)$ \\
\hline \multicolumn{5}{|l|}{ Month of injection, $\mathbf{n}(\%)$} \\
\hline September & $4(2.9)$ & $8(5.8)$ & $5(3.8)$ & $11(9.2)$ \\
\hline October & $7(5.0)$ & $4(2.9)$ & $4(3.1)$ & $2(1.7)$ \\
\hline November & $66(47.1)$ & $64(46.4)$ & $69(53.1)$ & $44(37.0)$ \\
\hline December & $43(30.7)$ & $45(32.6)$ & $32(24.6)$ & $50(42.0)$ \\
\hline January & $20(14.3)$ & $17(12.3)$ & $20(15.4)$ & $12(10.1)$ \\
\hline \multicolumn{5}{|l|}{ Date of dispensing of influenza vaccine } \\
\hline Minimum & 20 September 2010 & 20 September 2011 & 25 September 2012 & 23 September 2013 \\
\hline 5th percentile & 23 September 2010 & 28 September 2011 & 29 September 2012 & 04 October 2013 \\
\hline Median & 15 October 2010 & 21 October 2011 & 15 October 2012 & 25 October 2013 \\
\hline 95th percentile & 06 December 2010 & 01 December 2011 & 13 December 2012 & 04 December 2013 \\
\hline Maximum & 24 December 2010 & 23 December 2011 & 11 January 2013 & 10 January 2014 \\
\hline \multicolumn{5}{|l|}{ Date of injection of influenza vaccine } \\
\hline Minimum & 23 September 2010 & 22 September 2011 & 27 September 2012 & 23 September 2013 \\
\hline 5th percentile & 30 September 2010 & 03 October 2011 & 02 October 2012 & 07 October 2013 \\
\hline Median & 28 October 2010 & 02 November 2011 & 29 October 2012 & 07 November 2013 \\
\hline 95th percentile & 22 December 2010 & 06 January 2012 & 28 December 2012 & 10 January 2014 \\
\hline Maximum & 26 January 2011 & 24 January 2012 & 28 January 2013 & 29 January 2014 \\
\hline \multicolumn{5}{|l|}{ Duration of preinjection period, $d$} \\
\hline Mean & 64 & 67 & 64 & 72 \\
\hline SD & 27 & 27 & 28 & 28 \\
\hline
\end{tabular}


Table 2 Description of vaccinated patients according to the year of diagnosis of Guillain-Barre syndrome (GBS) (continued)

\begin{tabular}{|c|c|c|c|c|}
\hline Date of GBS & $\begin{array}{l}\text { September 1, 2010, } \\
\text { to March 31, } 2011\end{array}$ & $\begin{array}{l}\text { September 1, 2011, } \\
\text { to March 31, } 2012\end{array}$ & $\begin{array}{l}\text { September 1, 2012, } \\
\text { to March 31, } 2013\end{array}$ & $\begin{array}{l}\text { September 1, 2013, } \\
\text { to March 31, } 2014\end{array}$ \\
\hline \multicolumn{5}{|l|}{ Duration of control period, $d$} \\
\hline Mean & 105 & 103 & 104 & 97 \\
\hline SD & 27 & 27 & 28 & 28 \\
\hline \multicolumn{5}{|l|}{$\begin{array}{l}\text { Interval between dispensing and injection } \\
\text { of the vaccine, } d\end{array}$} \\
\hline Minimum & 0 & 0 & 0 & 0 \\
\hline 5th percentile & 0 & 0 & 0 & 0 \\
\hline Median (Q1-Q3) & $5(1-18.5)$ & $4(0-18)$ & $3(0-19)$ & $5(0-19)$ \\
\hline 95th percentile & 61 & 68 & 54 & 56 \\
\hline Maximum & 103 & 97 & 105 & 116 \\
\hline \multicolumn{5}{|l|}{$\begin{array}{l}\text { Interval between dispensing and injection } \\
\text { of the vaccine, } n(\%)\end{array}$} \\
\hline Dispensing and injection on the same day & $31(22.1)$ & $41(29.7)$ & $33(25.4)$ & $34(28.6)$ \\
\hline $\begin{array}{l}\text { Interval between dispensing and injection } \\
\text { of the vaccine } \leq 3 \mathrm{~d}\end{array}$ & $59(42.1)$ & $68(49.3)$ & $66(50.8)$ & $56(47.1)$ \\
\hline $\begin{array}{l}\text { Interval between dispensing and injection } \\
\text { of the vaccine } \leq 30 \mathrm{~d}\end{array}$ & $117(83.6)$ & $120(87.0)$ & $116(89.2)$ & $102(85.7)$ \\
\hline
\end{tabular}

Abbreviation: Q1 = first quartile; Q3 = third quartile.

mechanical ventilation. In sensitivity analyses, we modified the duration of the risk period ( 28 and 56 days). Analyses were also performed by considering that the risk period started on the date of influenza vaccine dispensing. All statistical analyses were performed with SAS software. ${ }^{33}$

\section{Standard protocol approvals, registrations, and patient consents}

This study was approved by the French data protection agency (Commission Nationale de l'Informatique et des Libertés) (regulatory decision DE-2011-078).

\section{Data availability}

The present data cannot be shared, for legal reasons. Applications to access the French health insurance claims data must be submitted to the Institut National des Données de Santé (indsante.fr/).

\section{Results}

\section{Patient characteristics}

We identified 7,855 incident cases of GBS from 2010 to 2014, with 903, 853, 932, and 835 cases diagnosed during the 2010-2011, 2011-2012, 2012-2013, and 2013-2014 influenza seasons, respectively. Among them, 3,523 patients met the eligibility criteria and were included in the analyses (figure 2). The mean age at diagnosis of GBS was 51 years, with a marked female predominance ( $58.4 \%$ women vs $41.6 \%$ men). A total of 1,055 patients (29.9\%) were admitted to an intensive care unit and 485 (13.8\%) patients required mechanical ventilation. Immunoglobulins were administered to $2,735(72 \%)$ patients and plasma exchange was performed in 122 patients $(3.5 \%)$ (table 1$)$.

Of all cases identified, 527 (15.0\%) were in patients who had received influenza vaccination. Two-thirds of them had been vaccinated with a split-virion inactivated influenza vaccine and one-third with an inactivated subunit influenza vaccine. For $339(64.3 \%)$ vaccinated patients, the date of injection corresponded to a medical visit with a general practitioner. The median interval between dispensing and injection was 4 days (Q1-Q3: 0-19). The mean duration of the control period was 107 days (Q1-Q3: 87-123). Depending on the influenza campaign, the median date for vaccine dispensing ranged from October 15 to October 21; for vaccine injection, October 28 to November 7; and the median interval between dispensing and injection ranged from 3 to 5 days (table 2).

\section{Association between GBS and infections}

The risk of developing GBS during the 42 days following an acute gastrointestinal infection or acute respiratory tract infection was increased compared to that of an infection-free period. The crude IRR of GBS was 3.73 ( $95 \%$ confidence interval [CI], 3.09-4.50; $p<0.0001)$ after an acute gastrointestinal infection and 3.99 (95\% CI, 3.62-4.41; $p<0.0001$ ) after an acute respiratory tract infection (table 3 ). 
Table 3 Incidence rate ratio of Guillain-Barré syndrome (GBS) following influenza vaccination or acute infections according to the self-controlled case series method

\begin{tabular}{|c|c|c|c|c|c|c|c|}
\hline & \multirow[b]{2}{*}{ No. } & \multicolumn{3}{|c|}{ Crude analysis } & \multicolumn{3}{|c|}{ Adjusted model ${ }^{a}$} \\
\hline & & IRR $_{\text {crude }}$ & $95 \% \mathrm{Cl}$ & $p$ Value & IRR $_{\text {adj }}$ & $95 \% \mathrm{Cl}$ & $p$ Value \\
\hline \multicolumn{8}{|l|}{ Influenza vaccination } \\
\hline More than $\mathbf{4 2}$ days postvaccination & 323 & Ref & & & Ref & & \\
\hline During the first $\mathbf{4 2}$ days after vaccination & 140 & $1.02^{\mathrm{b}}$ & $0.83-1.25$ & 0.85 & $1.10^{\mathrm{b}}$ & $0.89-1.37$ & 0.38 \\
\hline Before vaccination & 64 & $0.27^{\mathrm{b}}$ & $0.21-0.36$ & $<0.0001$ & $0.36^{\mathrm{b}}$ & $0.27-0.49$ & $<0.0001$ \\
\hline No vaccination & 2,996 & - & & & - & & \\
\hline \multicolumn{8}{|l|}{ Acute gastrointestinal infections } \\
\hline GBS before infection or more than $\mathbf{4 2}$ days after infection & 252 & Ref & & & Ref & & \\
\hline During the first $\mathbf{4 2}$ days after an infection & 255 & $3.73^{b}$ & $3.09-4.50$ & $<0.0001$ & $3.64^{\mathrm{b}}$ & $3.01-4.40$ & $<0.0001$ \\
\hline No infection & 3,016 & - & & & & & \\
\hline \multicolumn{8}{|l|}{ Acute respiratory tract infections } \\
\hline GBS before infection or more than $\mathbf{4 2}$ days after infection & 793 & Ref & & & Ref & & \\
\hline During the first $\mathbf{4 2}$ days after an infection & 1,009 & $3.99^{\mathrm{b}}$ & $3.62-4.41$ & $<0.0001$ & $3.89^{\mathrm{b}}$ & $3.52-4.30$ & $<0.0001$ \\
\hline No infection & 1721 & - & & & & & \\
\hline \multicolumn{8}{|l|}{ Month } \\
\hline September & 354 & Ref & & & Ref & & \\
\hline October & 419 & $1.15^{\mathrm{b}}$ & $0.99-1.32$ & 0.06 & $1.04^{\mathrm{b}}$ & $0.90-1.20$ & 0.63 \\
\hline November & 491 & $1.39^{b}$ & $1.21-1.59$ & $<0.0001$ & $1.18^{\mathrm{b}}$ & $1.02-1.36$ & 0.02 \\
\hline December & 493 & $1.35^{\mathrm{b}}$ & $1.18-1.54$ & $<0.0001$ & $1.13^{b}$ & $0.98-1.30$ & 0.09 \\
\hline January & 662 & $1.81^{b}$ & $1.59-2.06$ & $<0.0001$ & $1.44^{\mathrm{b}}$ & $1.26-1.65$ & $<0.0001$ \\
\hline February & 555 & $1.67^{\mathrm{b}}$ & $1.46-1.90$ & $<0.0001$ & $1.30^{\mathrm{b}}$ & $1.13-1.50$ & 0.0002 \\
\hline March & 549 & $1.50^{\mathrm{b}}$ & $1.31-1.72$ & $<0.0001$ & $1.20^{\mathrm{b}}$ & $1.04-1.38$ & 0.01 \\
\hline
\end{tabular}

Abbreviations: $\mathrm{Cl}=$ confidence interval; IRR = incidence rate ratio.

a Adjusted on all other variables listed in the table.

\section{Main analysis}

Of the 527 patients with GBS vaccinated against influenza, $140(26.6 \%)$ developed GBS in the 42 days following vaccination. In univariate analyses, we did not find evidence for an association between GBS and influenza vaccine $\left(\mathrm{IRR}_{\text {crude }}\right.$ 2010-2014, 1.02; 95\% CI, 0.83-1.25; $p=0.85$ ). Adjusting for calendar month and acute respiratory and gastrointestinal infections did not change the results ( $\mathrm{IRR}_{\mathrm{adj}} 2010-2014,1.10$; 95\% CI, 0.89-1.37; $p=0.38$ ). Moreover, 64 cases of GBS occurred in the prevaccination period and the rate of GBS was about 3 times lower in comparison to that of the control period (IRR adj 2010-2014, 0.36; 95\% CI, 0.27-0.49; $p<0.0001$ ) (table 3).

\section{Heterogeneity}

During the 2010/2011, 2011/2012, and 2013/2014 influenza season, we did not find evidence for an association between
GBS and vaccine. The adjusted IRR of the 2012/2013 influenza vaccination was 1.60 with a $\mathrm{CI}$ of $1.05-2.44$ and a $p$ value equal to 0.03 . Although we found this discordant result according to the influenza season, there was no evidence of heterogeneity between seasons (Cochran test: $p=0.23$ ) (table 4).

\section{Sensitivity analyses}

The risk of developing GBS during the 42-day risk period after influenza vaccination did not differ in the various subgroups, particularly the subgroup of patients aged 65 years or older, targeted by the French influenza vaccine recommendations $\left(\right.$ IRR $_{\text {adj }} 2010-2014,1.02 ; 95 \% \mathrm{CI}, 0.79-1.31 ; p=0.90$ ) (figure 3 ). Analysis of the 2 types of influenza vaccine, split-virion vs subunit influenza vaccine, also did not reveal any significant association with GBS over the following 42 days. Analysis of the cases in which the diagnosis of GBS appeared to be most 
certain (cases treated with immunoglobulins or plasma exchange) revealed a similar risk to that observed in the main analysis (IRR adj 2010-2014, 0.98; 95\% CI, 0.77-1.26; $p=0.89$ ). Similarly, in the most serious cases requiring intensive care unit admission or mechanical ventilation, influenza vaccine was not significantly associated with GBS (IRR adj 2010-2014, 0.79 ; 95\% CI, $0.53-1.18 ; p=0.25$ ).

Among all the sensitivity analyses, we found some evidence for an association between GBS and influenza vaccine when the period at risk was reduced to 28 days postvaccination, with a $p$ value equal to $0.047\left(\mathrm{RR}_{\mathrm{adj}}, 1.27 ; 95 \% \mathrm{CI}, 1.00-1.60\right)$ (figure 4 ). When a 56-day risk period after influenza vaccination was considered, there was no evidence for an association $(p=0.75)$. When the risk period started from the date of dispensing of the influenza vaccine, there was no evidence for an association, regardless of the duration of the risk period (figure 4).

\section{Discussion}

This study did not find evidence of an increased risk of GBS in a period of 42 days following influenza vaccination during vaccine campaigns from 2010 to 2014.

The main subgroup analyses and sensitivity analyses did not reveal an association between exposure to influenza vaccine and GBS. However, a weak association was observed for the 2012-2013 vaccine campaign. This result must be interpreted cautiously, as it may be a chance finding because subgroup analyses often lack power, and the test of heterogeneity did not put in evidence a difference between influenza seasons. However, in view of the various studies reporting an association between influenza virus infection and GBS, ${ }^{18,21,37,38}$ a possible effect related to the characteristics of the 2012-2013 influenza epidemic cannot be excluded. In France, the 2012-2013 influenza epidemic was particularly long (13 weeks) but only moderately severe. This epidemic was marked by the cocirculation of 3 influenza viruses (type A [H1N1], type A [H3N2], and type B [Victoria—not included in the vaccine $]) .{ }^{39}$

Initially, in 1976, studies reported an effect attributed to the swine influenza vaccine that lasted for at least 6 weeks and possibly for 8 weeks but not longer. ${ }^{4,9,10}$ Thus, in the majority of further studies evaluating the association between GBS and influenza vaccine, the period considered at risk was defined as 42 days following vaccination..$^{13,34,35}$ In our study, the sensitivity analysis conducted over a 56-day postvaccination period confirmed that there was no significant risk over this period. Nevertheless, we found some evidence for an increased rate of GBS in the 28 days postvaccination. The Canadian study by Kwong et al. ${ }^{20}$ suggested that the risk of GBS was increased, with the greatest risk during weeks $2-4$ after vaccination. Studies on the first month after vaccination could be developed in order to determine this association with higher accuracy. ${ }^{12,20}$ 
Figure 3 Incidence rate ratio (IRR) of Guillain-Barré syndrome (GBS) after influenza vaccination in various patient subgroups, according to the self-controlled case series method

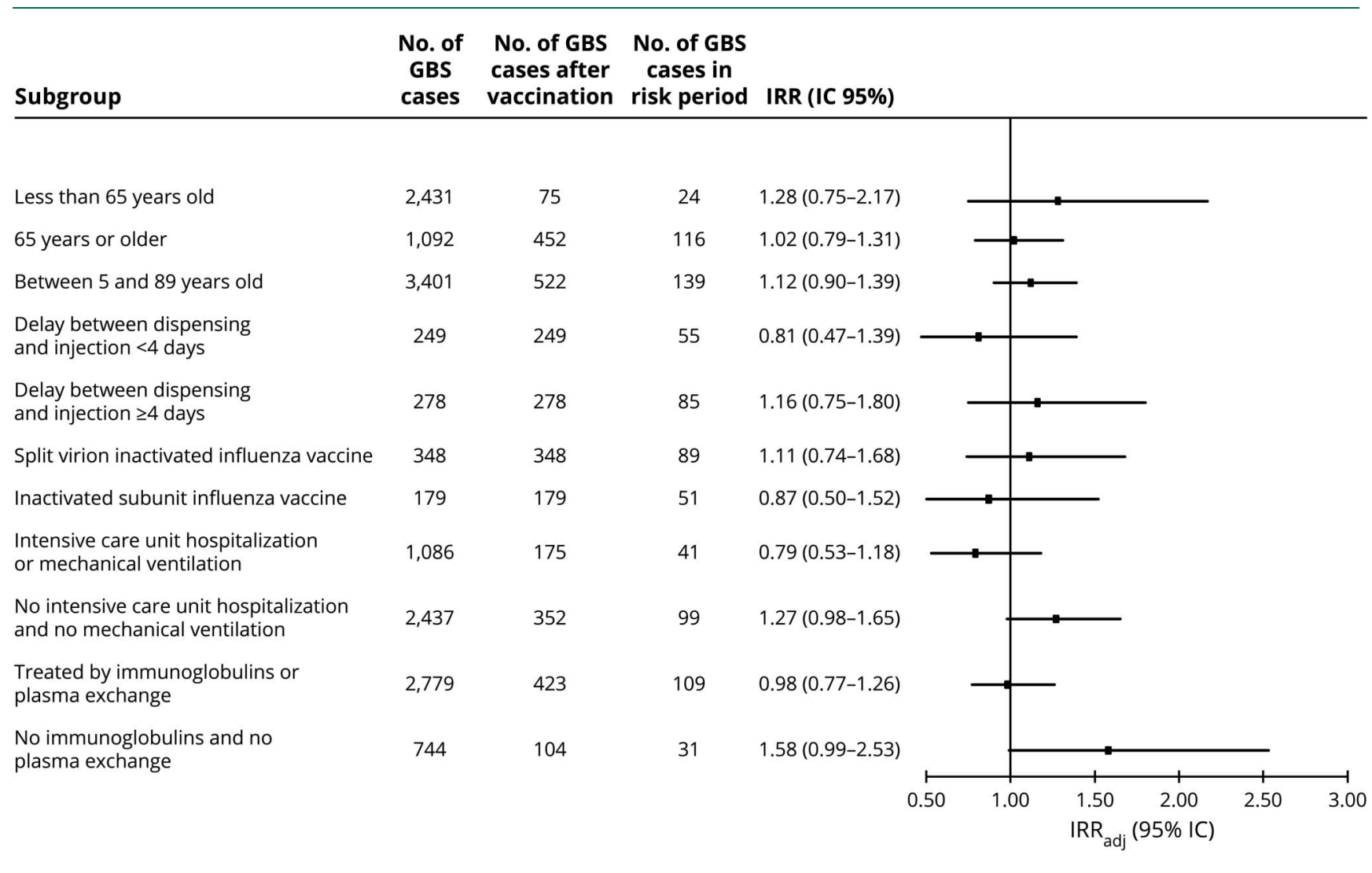

$\mathrm{IC}=$ confidence interval.

Although controversial in the scientific literature, ${ }^{14}$ our study provides strong arguments in favor of no significantly increased risk of GBS within 42 days of seasonal influenza vaccination.

Our study had several strengths. In particular, it was conducted using comprehensive French health care data, which allowed us to include more than 3,500 cases of GBS, despite the rarity of this disease. With 527 cases of vaccinated GBS, our study had a power to detect an IRR of 1.5 , with an $\alpha$ risk of $5 \%$, greater than $90 \%{ }^{40}$ To our knowledge, this study was the most powerful on the subject.

The case identification algorithm corresponded to a method described in the article by Delannoy et al. ${ }^{2}$ This algorithm had

Figure 4 Incidence rate ratio (IRR) of Guillain-Barré syndrome after influenza vaccine, sensitivity analyses

\section{IRR (IC 95\%)}

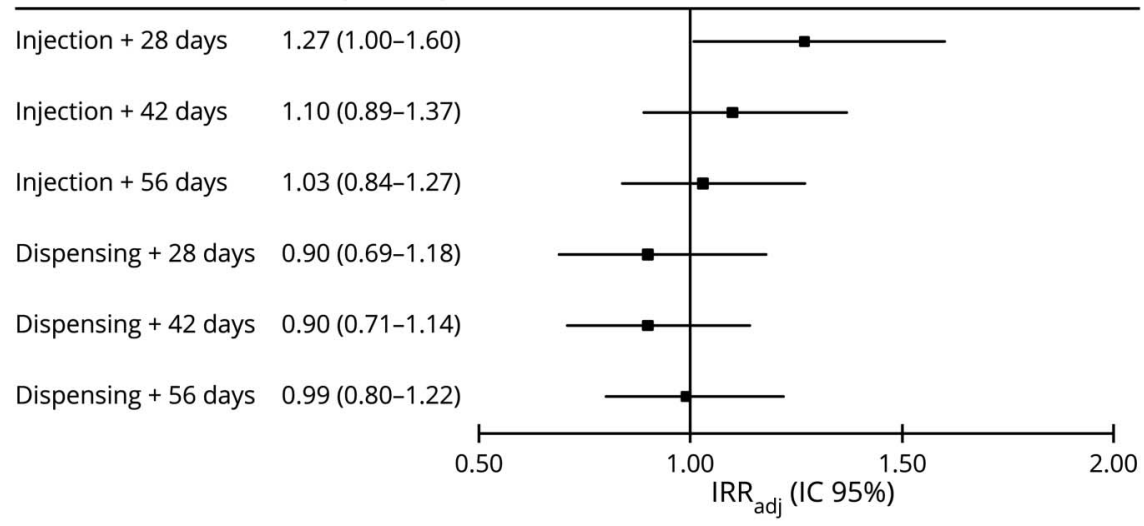

IC = confidence interval. 
estimated a world standardized incidence rate of 2.0 per 100,000 person-years in France. This incidence is in accordance with the international literature, situated in the upper range of previous estimates of GBS incidence in Europe and North America. ${ }^{1,2}$ Nevertheless, this algorithm did not plan any confirmation of GBS cases based on chart review or on Brighton criteria. Thus we could not exclude cases of potential mimics of GBS or acute onset of chronic neuropathies if encoded in G61.0 (GBS). However, this concordance with incidences found in other studies and population characteristics were in favor of good validity of the algorithm. Sensitivity analyses on the most certain cases (immunoglobulins or plasma) showed similar results.

The study design (SCCS) considered all constant confounding factors during the study period, such as genetic factors. Acute respiratory tract and gastrointestinal infections, which are time-dependent confounding factors, were considered in adjusted models. We also adjusted over calendar month to take into account the effect of seasonality since there is an increased risk of GBS in winter compared to summer and was therefore a potential time-dependent confounding factor. $^{2,31}$ This SCCS design is useful for pharmacoepidemiology and vaccine safety studies. One of the hypotheses to explain the conflicting results of the scientific literature could be the use of different designs less suitable for vaccine safety studies, or the failure to consider potential confounding factors. $^{32,41-44}$

Finally, the study was conducted only on periods of influenza risk and thus on periods when patients could potentially be vaccinated against influenza. During the months of April to August, people living in metropolitan France were not vaccinated against seasonal influenza and therefore no case of GBS could be linked to vaccination during this period. One of the strengths of this study is that it did not consider the prevaccination period to be the control period for the analyses. The risk of GBS was significantly decreased during the prevaccination period compared to the control period, indicating that the development of GBS may lead to deferral of vaccination or may be considered to constitute a contraindication to influenza vaccination in clinical practice. Failure to consider this prevaccination period as a period of reduced risk of GBS would have led to a bias in the estimation of the baseline risk (during the control period), and thus artificially increased the risk of GBS after vaccination compared to this period. This could be another hypothesis to explain the differences observed between the studies, when the prevaccination period was not considered.

Our study presents several limitations. First, identification of acute respiratory tract and gastrointestinal infections was based on the treatments reimbursed by national health insurance and hospitalizations. Although we reduced the selection to the most specific treatment, it could not be excluded that some drug dispensing did not correspond to an acute infection. On the other hand, we could not identify all infections and we could not accurately identify influenza infections because they do not always require medical attention and prescription of a specific and reimbursed treatment. Medically treated acute infection variables were therefore used as proxies of acute infections. However, the risk of GBS was fourfold higher during the 42 days following an acute respiratory tract or gastrointestinal infection. This strong association between acute infections and GBS has already been reported in the scientific literature and supports our methodology and our results. ${ }^{3,16,45,46}$ Furthermore, adjustment for calendar month took into account underlying seasonal infections that cannot be identified by reimbursed treatments.

Second, in the SNIIRAM database, the only date available to estimate the date of vaccine injection is the date of vaccine dispensing. The date of vaccine injection, corresponding to the start of exposure, was therefore estimated from the dates of consultations and billing of medical and paramedical procedures. The study by Hanf et al., ${ }^{47}$ also based on French claims databases, demonstrated the validity of using these databases for vaccine safety studies based on these types of hypotheses. Using our hypothesis concerning the date of injection, the median interval between vaccine dispensing and vaccine injection was estimated to be 4 days, which appears to be consistent with appointment waiting times in France. ${ }^{48}$ However, a classification bias remains possible if the patient is vaccinated by a relative (or by himself or herself) or if the patient was not vaccinated during the visit following dispensing. Nevertheless, our sensitivity analyses considering the date of vaccine dispensing as the start date of the risk period revealed similar results to those of the main analysis.

Regular new pharmacoepidemiology studies on influenza vaccine remain justified because the composition of the vaccine varies each year. Nevertheless, our findings are reassuring, as we did not find evidence of an increased risk of GBS within 42 days following seasonal influenza vaccination. We highlight that this risk is increased in presence of acute respiratory tract or gastrointestinal infections (including influenza).

\section{Acknowledgment}

The authors thank Anthony Saul for English revision of the manuscript.

\section{Study funding}

French National Health Insurance.

\section{Disclosure}

The authors report no disclosures relevant to the manuscript. Go to Neurology.org/N for full disclosures.

\section{Publication history}

Received by Neurology August 1, 2019. Accepted in final form November 22, 2019. 
Appendix Authors

\begin{tabular}{|c|c|c|}
\hline Name & Location & Contribution \\
\hline $\begin{array}{l}\text { Clémence } \\
\text { Grave, MD }\end{array}$ & $\begin{array}{l}\text { Department of Studies in } \\
\text { Public Health, French } \\
\text { National Health Insurance, } \\
\text { Paris, France }\end{array}$ & $\begin{array}{l}\text { Designed and } \\
\text { conceptualized study, } \\
\text { analyzed the data, } \\
\text { interpreted the data, } \\
\text { drafted the manuscript for } \\
\text { intellectual content }\end{array}$ \\
\hline
\end{tabular}

$\begin{array}{ll}\text { Pauline } & \text { Department of Studies in } \\ \text { Boucheron, } & \text { Public Health, French } \\ \text { MD, MSc } & \text { National Health Insurance, } \\ & \text { Paris, France }\end{array}$

Designed and conceptualized study, analyzed the data, interpreted the data, drafted the manuscript for intellectual content

\begin{tabular}{ll}
\hline Jérémie & Department of Studies in \\
Rudant, & Public Health, French \\
MD, PhD & National Health Insurance, \\
& Paris, France
\end{tabular}

Designed and conceptualized study, interpreted the data, revised the manuscript for intellectual content

\begin{tabular}{ll}
\hline Yann & Assistance Publique- \\
Mikaeloff, & Hôpitaux de Paris, Hôpital \\
MD, PhD & Bicêtre, Unité de \\
& Rééducation Neurologique \\
& Infantile, Bicêtre; CESP, \\
& Faculté de Médecine- \\
& Université Paris-Sud, \\
& Faculté de Médecine- \\
& UVSQ, INSERM, Université \\
& Paris-Saclay, Villejuif, \\
& France
\end{tabular}

\begin{tabular}{ll}
\hline Pascale & Biostatistics and \\
Tubert- & Pharmacoepidemiology, \\
Bitter, PhD & Inserm U1181 (B2PHI), \\
& UVSQ, University Paris \\
& Saclay, Institut Pasteur, \\
& France
\end{tabular}

Designed and conceptualized study, interpreted the data, revised the manuscript for intellectual content

\section{Designed and}

conceptualized study,

interpreted the data,

revised the manuscript for intellectual content

\begin{tabular}{ll}
\hline Sylvie & Biostatistics and \\
Escolano, & Pharmacoepidemiology, \\
PhD & Inserm U1181 (B2PHI), \\
& UVSQ, University Paris \\
& Saclay, Institut Pasteur, \\
& France
\end{tabular}

Mounia N. Laboratoire Modélisation, Hocine, PhD Epidémiologie et Surveillance des Risques Sanitaires, Conservatoire National des Arts et Métiers, Paris, France

\begin{tabular}{lll}
\hline $\begin{array}{l}\text { Joël Coste, } \\
\text { MD, PhD }\end{array}$ & $\begin{array}{l}\text { Department of Studies in } \\
\text { Public Health, French } \\
\text { National Health Insurance, } \\
\text { Paris, France }\end{array}$ & $\begin{array}{l}\text { Interpreted the data, } \\
\text { revised the manuscript for } \\
\text { intellectual content }\end{array}$ \\
\hline $\begin{array}{l}\text { Alain Weill, } \\
\text { MD }\end{array}$ & $\begin{array}{l}\text { Department of Studies in } \\
\text { Public Health, French } \\
\text { National Health Insurance, } \\
\text { Paris, France }\end{array}$ & $\begin{array}{l}\text { Designed and } \\
\text { conceptualized study, } \\
\text { interpreted the data, } \\
\text { revised the manuscript for } \\
\text { intellectual content }\end{array}$ \\
\end{tabular}

\section{References}

1. McGrogan A, Madle GC, Seaman HE, de Vries CS. The epidemiology of GuillainBarré syndrome worldwide: a systematic literature review. Neuroepidemiology 2009; 32:150-163.

2. Delannoy A, Rudant J, Chaignot C, Bolgert F, Mikaeloff Y, Weill A. Guillain-Barré syndrome in France: a nationwide epidemiological analysis based on hospital discharge data (2008-2013). J Peripher Nerv Syst 2017;22:51-58.

3. Willison HJ, Jacobs BC, van Doorn PA. Guillain-Barré syndrome. Lancet 2016;388: $717-727$.

4. Haber P, Sejvar J, Mikaeloff Y, DeStefano F. Vaccines and Guillain-Barré syndrome. Drug Saf 2009;32:309-323.
5. Principi N, Esposito S. Vaccine-preventable diseases, vaccines and Guillain-Barré syndrome. Vaccine 2019;37:5544-5550.

6. Andrews N, Stowe J, Miller E. No increased risk of Guillain-Barré syndrome after human papilloma virus vaccine: a self-controlled case-series study in England. Vaccine 2017;35:1729-1732.

7. Miranda S, Chaignot C, Collin C, Dray-Spira R, Weill A, Zureik M. Human papillomavirus vaccination and risk of autoimmune diseases: a large cohort study of over 2 million young girls in France. Vaccine 2017;35:4761-4768.

8. Schonberger LB, Bregman D, Sullivan-Bolyai JZ, Bryan L, Noble GR. Guillain-Barre syndrome after administration of killed vaccines. Dev Biol Stand 1977;39:295-296.

9. Langmuir AD, Bregman DJ, Kurland LT, Nathanson N, Victor M. An epidemiologic and clinical evaluation of Guillain-Barré syndrome reported in association with the administration of swine influenza vaccines. Am J Epidemiol 1984;119:841-879.

10. Langmuir AD. Guillain-Barré syndrome: the swine influenza virus vaccine incident in the United States of America, 1976-77: preliminary communication. J R Soc Med 1979;72:660-669.

11. Prestel J, Volkers P, Mentzer D, et al. Risk of Guillain-Barré syndrome following pandemic influenza A(H1N1) 2009 vaccination in Germany. Pharmacoepidemiol Drug Saf 2014;23:1192-1204.

12. De Wals P, Deceuninck G, Toth E, et al. Risk of Guillain-Barré syndrome following H1N1 influenza vaccination in Quebec. JAMA 2012;308:175-181.

13. Salmon DA, Proschan M, Forshee R, et al. Association between Guillain-Barré syndrome and influenza A (H1N1) 2009 monovalent inactivated vaccines in the USA: a meta-analysis. Lancet 2013;381:1461-1468.

14. Martín Arias LH, Sanz R, Sáinz M, Treceño C, Carvajal A. Guillain-Barré syndrome and influenza vaccines: a meta-analysis. Vaccine 2015;33:3773-3778.

15. Baxter R, Bakshi N, Fireman B, et al. Lack of association of Guillain-Barré syndrome with vaccinations. Clin Infect Dis 2013;57:197-204.

16. Burwen DR, Ball R, Bryan WW, et al. Evaluation of Guillain-Barré Syndrome among recipients of influenza vaccine in 2000 and 2001. Am J Prev Med 2010;39:296-304.

17. Hughes RA, Charlton J, Latinovic R, Gulliford MC. No association between immunization and Guillain-Barré syndrome in the United Kingdom, 1992 to 2000. Arch Intern Med 2006;166:1301-1304.

18. Iqbal S, Li R, Gargiullo P, Vellozzi C. Relationship between Guillain-Barré syndrome, influenza-related hospitalizations, and influenza vaccine coverage. Vaccine 2015;33: 2045-2049.

19. Galeotti F, Massari M, D'Alessandro R, et al. Risk of Guillain-Barré syndrome after 2010-2011 influenza vaccination. Eur J Epidemiol 2013;28:433-444.

20. Kwong JC, Vasa PP, Campitelli MA, et al. Risk of Guillain-Barré syndrome after seasonal influenza vaccination and influenza health-care encounters: a self-controlled study. Lancet Infect Dis 2013;13:769-776.

21. Stowe J, Andrews N, Wise L, Miller E. Investigation of the temporal association of Guillain-Barre syndrome with influenza vaccine and influenzalike illness using the United Kingdom General Practice Research Database. Am J Epidemiol 2009;169: 382-388.

22. Tuppin P, Rudant J, Constantinou P, et al. Value of a national administrative database to guide public decisions: from the Système National d'Information Interrégimes de l'Assurance Maladie (SNIIRAM) to the Système National des Données de Santé (SNDS) in France. Rev Epidemiol Sante Publique 2017;65(suppl 4):S149-S167.

23. Tuppin P, de Roquefeuil L, Weill A, Ricordeau P, Merlière Y. French national health insurance information system and the permanent beneficiaries sample. Rev Epidemiol Sante Publique 2010;58:286-290.

24. Moulis G, Lapeyre-Mestre M, Palmaro A, Pugnet G, Montastruc J-L, Sailler L. French health insurance databases: what interest for medical research? Rev Med Interne 2015;36:411-417.

25. Bezin J, Francis F, Nguyen NV, et al. Impact of a public media event on the use of statins in the French population. Arch Cardiovasc Dis 2017;110:91-98.

26. World Health Organization. Recommended composition of influenza virus vaccines for use in the 2010-2011 northern hemisphere influenza season: February 2010: weekly epidemiological record, no. 10. Geneva: World Health Organization;2010.

27. World Health Organization. Recommended composition of influenza virus vaccines for use in the 2011-2012 northern hemisphere influenza season: February 2011: weekly epidemiological record, no. 10. Geneva: World Health Organization;2011.

28. World Health Organization. Recommended composition of influenza virus vaccines for use in the 2012-2013 northern hemisphere influenza season: February 2012: weekly epidemiological record, no. 10. Geneva: World Health Organization; 2012.

29. World Health Organization. Recommended composition of influenza virus vaccines for use in the 2013-2014 northern hemisphere influenza season: February 2013: weekly epidemiological record, no. 10. Geneva: World Health Organization;2013.

30. Rudant J, Dupont A, Mikaeloff Y, Bolgert F, Coste J, Weill A. Surgery and risk of Guillain-Barré syndrome: a French nationwide epidemiologic study. Neurology 2018; 91:e1220-e1227.

31. Whitaker HJ, Farrington CP, Spiessens B, Musonda P. Tutorial in biostatistics: the self-controlled case series method. Stat Med 2006;25:1768-1797.

32. Weldeselassie YG, Whitaker HJ, Farrington CP. Use of the self-controlled case-series method in vaccine safety studies: review and recommendations for best practice. Epidemiol Infect 2011;139:1805-1817.

33. Hocine MN, Chavance M. The case series method [in French]. Rev Epidemiol Sante Publique 2010;58:435-440.

34. Grimaldi-Bensouda L, Alpérovitch A, Besson G, et al. Guillain-Barre syndrome, influenzalike illnesses, and influenza vaccination during seasons with and without circulating A/H1N1 viruses. Am J Epidemiol 2011;174:326-335. 
35. Juurlink DN, Stukel TA, Kwong J, et al. Guillain-Barré syndrome after influenza vaccination in adults: a population-based study. Arch Intern Med 2006;166: 2217-2221.

36. Petersen I, Douglas I, Whitaker H. Self controlled case series methods: an alternative to standard epidemiological study designs. BMJ 2016;354:i4515.

37. Tam CC, O’Brien SJ, Petersen I, Islam A, Hayward A, Rodrigues LC. GuillainBarré syndrome and preceding infection with campylobacter, influenza and Epstein-Barr virus in the general practice research database. PLoS One 2007;2: e344.

38. Dodd CN, Romio SA, Black S, et al. International collaboration to assess the risk of Guillain Barré syndrome following influenza A (H1N1) 2009 monovalent vaccines. Vaccine 2013;31:4448-4458.

39. Équipes de Surveillance de la Grippe. Surveillance épidémiologique et virologique de la grippe en France, saison 2011-2012. Bull Épidemiol Hebd 2013:394-401.

40. Musonda P, Farrington CP, Whitaker HJ. Sample sizes for self-controlled case series studies. Stat Med 2006;25:2618-2631.

41. Farrington CP. Relative incidence estimation from case series for vaccine safety evaluation. Biometrics 1995;51:228-235.
42. Gault N, Castañeda-Sanabria J, Guillo S, Foulon S, Tubach F. Underuse of selfcontrolled designs in pharmacoepidemiology in electronic healthcare databases: a systematic review. Pharmacoepidemiol Drug Saf 2016;25:372-377.

43. Maclure M, Fireman B, Nelson JC, et al. When should case-only designs be used for safety monitoring of medical products? Pharmacoepidemiol Drug Saf 2012;21(suppl 1):50-61.

44. Nordmann S, Biard L, Ravaud P, Esposito-Farèse M, Tubach F. Case-only designs in pharmacoepidemiology: a systematic review. PLoS One 2012;7:e49444.

45. Yuki N, Hartung H-P. Guillain-Barré syndrome. N Engl J Med 2012;366:2294-2304.

46. Greene SK, Rett MD, Vellozzi C, et al. Guillain-Barré syndrome, influenza vaccination, and antecedent respiratory and gastrointestinal infections: a case-centered analysis in the vaccine safety datalink, 2009-2011. PLoS One 2013;8:e67185.

47. Hanf M, Quantin C, Farrington P, et al. Validation of the French national health insurance information system as a tool in vaccine safety assessment: application to febrile convulsions after pediatric measles/mumps/rubella immunization. Vaccine 2013;31:5856-5862.

48. Millien C, Chaput H, Cavillon M. La moitié des rendez-vous sont obtenus en 2 jours chez le généraliste, en 52 jours chez l'ophtalmologiste. In: Études Résultats, n1085. Paris: Ministry of Social Affairs and Health Research, Studies, Evaluation and Statistics Department (Drees); 2018. 


\section{Neurology}

\section{Seasonal influenza vaccine and Guillain-Barré syndrome: A self-controlled case series study}

Clémence Grave, Pauline Boucheron, Jérémie Rudant, et al.

Neurology 2020;94;e2168-e2179 Published Online before print February 25, 2020

DOI 10.1212/WNL.0000000000009180

This information is current as of February 25, 2020

Updated Information \& Services

References

Citations

Subspecialty Collections

Permissions \& Licensing

Reprints including high resolution figures, can be found at: http://n.neurology.org/content/94/20/e2168.full

This article cites 42 articles, 2 of which you can access for free at: http://n.neurology.org/content/94/20/e2168.full\#ref-list-1

This article has been cited by 3 HighWire-hosted articles: http://n.neurology.org/content/94/20/e2168.full\#\#otherarticles

This article, along with others on similar topics, appears in the following collection(s):

All CBMRT/Null Hypothesis

http://n.neurology.org/cgi/collection/all_cbmrt_null_hypothesis All epidemiology

http://n.neurology.org/cgi/collection/all_epidemiology

Guillain-Barre syndrome

http://n.neurology.org/cgi/collection/guillainbarre_syndrome

Risk factors in epidemiology

http://n.neurology.org/cgi/collection/risk_factors_in_epidemiology

Information about reproducing this article in parts (figures,tables) or in its entirety can be found online at:

http://www.neurology.org/about/about_the_journal\#permissions

Information about ordering reprints can be found online:

http://n.neurology.org/subscribers/advertise

Neurology ${ }^{\circledR}$ is the official journal of the American Academy of Neurology. Published continuously since 1951, it is now a weekly with 48 issues per year. Copyright () 2020 American Academy of Neurology. All rights reserved. Print ISSN: 0028-3878. Online ISSN: 1526-632X.

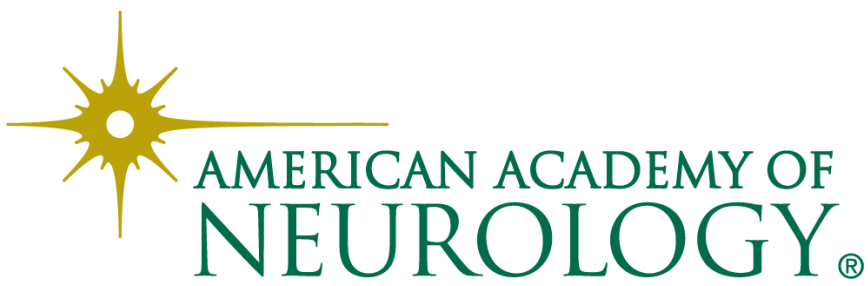

